\title{
PEWARISAN PADA MASYARAKAT ADAT BALI TERKAIT AHLI WARIS YANG BERALIH AGAMA
}

\author{
Oleh: \\ Ni Nyoman Sukerti, Ida Bagus Putra Atmadja, I G. A. Mas Rwa Jayantiari, \\ I G. A. Tirta Sari Dewi, I G. A. Bagus Agastya Pradnyana.
}

\section{ABSTRAK}

Penelitian ini bertujuan untuk menggali dan menganlisis tentang kedudukan ahli waris yang beralih agama dalam hal hak dan kewajibannya baik dalam keluarga maupun dalam masyarakat adat serta akibat hukum yang timbul terkait ahli waris yang beralih agama tersebut. Penelitian ini merupakan penelitian hukum empiris, dengan pendekatan non doktrinal (socio legal reseach). Data digali dengan metode wawancara, selanjutnya dianalisis secara kualitatif. Hasil penelitian menunjukan bahwa ahli waris yang beralih agama tidak lagi berkedudukan ahli waris. Akibatnya ahli waris yang bersangkutan gugur hak warisnya dari orang tuanya. Gugurnya hak mewaris berakibat tidak ada kewajiban-kewajiban yang harus dipikulnya baik kewajiban terhadap keluarga maupun terhadap masyarakat adat. Ahli waris yang beralih agama dikaji dari teorinya Lawrence $M$. Friedman tentang sistem hukum terdiri dari tiga unsur yaitu struktur hukum, substansi hukum dan budaya hukum, dimana dari ketiga unsur itu tidak mengalami perkembangan. Dengan demikian hukum adat waris Bali masih dipertahankan secara utuh.

Kata kunci: Pewarisan, masyarakat adat Bali, Ahli waris, beralih agama

\begin{abstract}
This study aims to explore and analyze about the position of heir converts in terms of rights and obligations both within the family and in indigenous communities as well as relevant legal consequences arising heir switch religions. This study is an empirical law, with non-doctrinal approach (socio legal research). Data extracted with interviews, analyzed qualitatively. The results showed that the heirs are turning religion is no longer a resident heir. Consequently heir in question fall heir rights of parents. The death of heir rights cause no obligations to be assuming both obligations towards the family and towards indigenous peoples. Heir converts studied from Lawrence M. Friedman's theory about the legal system consists of three elements, namely the legal structure, the substance of the law and legal culture, which of the three elements that are not experiencing growth. Thus the customary law of inheritance Bali still preserved intact.
\end{abstract}

Key word: Inheritance, Bali indigenous communities, heir, switch religion

\section{PENDAHULUAN}

Negara Indonesia sudah berumur 70 tahun, dengan umur demikian sudah cukup banyak peraturan perundangundangan yang berhasil dibuat, namun dalam bidang hukum keluarga dan hukum waris belum berhasil dibuat sampai sekarang. Oleh karena demikian maka dalam hukum keluarga dan hukum waris masih berlaku berbagai bidang hukum yaitu hukum adat, hukum islam dan Kitab UndangUndang Hukum Perdata (KUHPerdata) bagi golongan-golongan masyarakat tertentu.

Dalam kajian ini fokus kajiannya adalah tentang hukum adat waris Bali dan secara khusus terkait ahli waris yang beralih agama dari agama Hindu ke non Hindu. Mengkaji masalah pewarisan maka awal kajian tidak dapat lepas dari sistem kekerabatan atau kekeluargaan yang dianut oleh masyarakat yang bersangkutan. Sistem kekerabatan yang dianut masyarakat akan berpengaruh terhadap bentuk 
perkawinan yang dilakukannya dan bentuk perkawinan yang dilakukan akan mempengaruhi masalah pewarisan yang dianut oleh suatu masyarakat adat tertentu. Pada umumnya di Indonesia dikenal tiga sistem kekeluargaan yaitu sistem kekeluargaan patrilineal, sistem kekeluargaan matrilineal dan sistem kekeluargaan parental. Sistem kekeluargaan patrilineal adalah sistem kekerabatan dimana keturunan dihitung menurut garis laki-laki (ayah) saja. Sementara sistem kekeluargaan matrilineal adalah sistem kekeluargaan dimana keturunan dihitung dari garis perempuan (ibu) saja, dan sistem kekeluargaan parental adalah dimana keturunan dilihat atau dilacak baik dari garis laki-laki dan perempuan (ayah-ibu)

Masyarakat adat Bali Hindu menganut sistem kekeluargaan atau kekerabatan patrilineal yang lebih dikenal dengan istilah sistem "purusa", kecuali masyarakat adat Tenganan Pagringsingan di Karangsem, dimana masyarakat tersebut menganut sistem kekeluargaan parental. Jadi masyarakat Bali Hindu tidak sepenuhnya menganut sistem kekeluargaan patrilineal. Pada sistem purusa garis keturunan dilacak atau ditarik dari garis ayah. Ini berarti anak laki-laki sebagai pelanjut keturunan. Konsekunsinya anak lakilaki yang berkedudukan sebagai ahli waris, namun demikian ada kalanya anak perempuan juga dapat berkedudukan sebagai ahli waris dengan cara melakukan perkawinan nyeburin. Cara perkawinan nyeburin ditempuh karena tidak adanya anak laki-laki sebagai pelanjut keturunan. Ini berarti cara perkawinan nyeburin sejatinya adalah untuk mempertahankan sistem purusa. Oleh karena demikian maka tidak serta merta semua anak perempuan Bali dapat melakukan perkawinan nyeburin dan berkedudukan sebagai ahli waris karena untuk dapat melakukan perkawinan nyeburin harus ada beberapa persyaratan yang mesti dipenuhi.

Untuk dapat berlangsungnya proses pewarisan ada tiga unsur yang sangat esensial yang harus dipenuhi yaitu pewaris, harta warisan dan ahli waris. Apabila salah satu dari unsur esensial tidak ada maka pewarisan tidak dapat dilaksanakan. Dalam hal proses pewarisan dimana ada ahli waris beralih agama dari agama Hindu menjadi non Hindu dapat menimbulkan persoalan baik dalam keluarga maupun dalam masyarakat adat terkait dengan hak-hak dan kewajiban-kewajibannya karena hak dan kewajiban selalu berdampingan terlebih yang menyangkut kewajiban keagamaan dan kemasyarakatan. Sehubungan dengan adanya dua hal yang tidak dapat dipisahkan yakni hak dan kewajiban tersebut maka penelitian ini menjadi penting dilakukan untuk menemukan jawabannya.

\section{Rumusan Masalah}

Berdasarkan apa yang sudah diuraikan di atas maka masalah penting yang menjadi fokus pada penelitian ini yaitu bagaimanakah kedudukan hukum ahli waris yang beralih agama dan akibat hukum apakah yang timbul terkait ahli waris beralih agama pada masyarakat adat Bali ? 


\section{METODE PENELITIAN}

\section{Jenis dan Sifat Penelitian}

Penelitian tentang pewarisan pada masyarakat adat Bali terkait ahli waris yang peralih agama adalah merupakan penelitian hukum empiris yang merupakan data lapangan sebagai data primer. Penelitian ini tidak akan menguji hipotesis, akan tetapi menggali informasi sebanyak mungkin sehubungan dengan pewarisan pada masyarakat adat Bali terkait ahli waris yang beralih agama. Oleh karenanya penelitian ini bersifat deskritif, yaitu menggambarkan atau menjelaskan tentang kedudukan ahli waris yang beralih agama dan akibat-akibat yang timbul terkait dengan hak-hak dan kewajiban-kewajibannya sebagai ahli waris.

\section{Jenis dan Sumber Data}

Dalam penelitian ini data yang digali dan dikumpulkan adalah berupa data primer dan data sekunder. Data primer yakni data yang diperoleh dari sumber data lapangan di Desa Pakraman Canggu, Kuta Utara, Badung. Lokasi penelitian ditentukan secara purposif dengan dasar pertimbangan bahwa di desa pakraman tersebut ada warga Hindu yang beralih agama ke non Hindu. Penentuan informannya ditentukan dengan teknik snow ball (bola salju), informan yang dipilih adalah tokoh masyarakat, bendesa dan beberapa warga masyarakat hukum adat atau Desa Pakraman Canggu, yang berasal dari Banjar Kayu Tulang, Banjar Pipitan, Banjar Tegal Gundul dan Banjar Pengilian sebagai sampel. Dimana desa pakraman tersebut secara administarsi berada di Kecamatan Kuta Utara, Kabupaten Badung.

Data sekunder diperoleh dari bahan-bahan tertulis atau dokumendokumen yang memuat informasi seperti buku, kamus, laporan penelitian sehubungan dengan pewarisan pada umumnya dan pada masyarakat adat Bali khususnya .

\section{Teknik Pengumpulan Data.}

Untuk mendapatkan data yang diperlukan dan data yang akurat, teknik pengumpulan data yang digunakan dalam penelitian ini adalah teknik wawancara (interview) yang berpedoman pada pedoman pertanyaan (interview guide).

\section{Teknik Pengolahan Data}

Setelah data yang diperlukan terkumpul maka langkah selanjutnya adalah tahap pengolahan dan analisis data. Dalam penglahan dan analisis data dilakukan dengan menggunakan metode yang bersifat kualitatif dilengkapi dengan analisis situasional. Metode ini akan dapat menunjukan tentang pewarisan pada masyarakat adat Bali dalam hal ini di Desa Pakraman Canggu terkait ahli waris yang beralih agama dari agama Hindu menjadi non Hindu.

\section{HASIL DAN PEMBAHASAN}

\section{Tinjauan Umum Hukum Adat Waris Bali.}

Mengkaji hukum adat waris Bali, kajian mana tidak dapat lepas dari hukum adat waris Indonesia. Indonesia merupakan negara yang pendudukan terdiri dari bermacam-macam suku bangsa dan masing-masing suku bangsa mempunyai tata aturan di bidang waris, yang tentunya tidak 
sama satu dengan yang lainnya, ini tergantung dari sistem kekeluragaan dan bentuk perkawinan yang dianut oleh masyarakat hukum adat yang bersangkutan. Berlakunya hukum adat waris yang tidak sama antara suku bangsa yang satu dengan suku bangsa yang lainnya dikarenakan belum berhasilnya pemerintah membuat hukum waris yang berlaku secara nasional. Sebenarnya gagasan untuk membuat hukum keluarga dan hukum waris nasional sudah ada sejak lama sebagimana diuraikan oleh Hazairin. Untuk membuat hukum waris nasional sudah digagas sejak tahun 1960, seperti diamanatkan oleh TAP MPRS Nomor II Tahun 1960, pada angka 402 huruf $c$ sub 2 Ketetapan MPRS tersebut dinyatakan bahwa perlunya perundang-undangan mengenai hukum waris yang berlandaskan prinsipprinsip kewarisan parental bilateral ${ }^{1}$.

Apa yang diamanatkan oleh TAP MPRS tersebut belum terwujud sampai sekarang bahkan diusia negara kita sudah berumur70 tahun, walaupun demikian dalam bidang hukum lainnya banyak peraturan perundang-undangan yang berhasil dibuatnya. Terkait belum adanya hukum waris nasional maka dalam bidang kewarisan berlaku hukum waris adat di samping hukum waris Islam dan hukum waris Barat atau Kitab Undang-Undang Hukum Perdata (KUHPerdata) dengan kata lain dalam bidang hukum waris masih berlaku pluralisme hukum dan pluralisme hukum tersebut berlaku terhadap golongan-golongan masyarakat tertentu. Dalam kaitan ini

${ }^{1}$ Hazairin, Hukum Kekeluargaan Nasional, Tintamas, Jakarta, 1982, h. 1. yang menjadi fokus kajian ditekankan pada hukum adat waris Bali. Hukum adat waris Bali yang menurut Windia, hukum waris bagi orang Bali adalah hukum adat waris Bali ${ }^{2}$.

Soepomo mengatakan hukum adat waris adalah memuat peraturanperaturan yang mengatur proses peneruskan serta mengoperkan barangbarang harta benda dan barang-barang yang tidak bewujud benda (immateriele goedren) dari suatu angkatan manusia (generatie) kepada turunannya ${ }^{3}$.

Sementara Surojo Wignjodipuro mengatakan bahwa hukum adat waris meliputi norma-norma hukum yang menetapkan harta kekayaan baik yang materiil maupun yang immateriil yang manakah dari seseorang yang dapat diserahkan kepada keturunannya serta yang sekaligus juga mengatur saat, cara dan proses peralihannya ${ }^{4}$.

Mencermati definisi dari kedua sarjana tersebut di atas pada dasarnya tidak jauh berbeda karena secara garis besarnya dikemukakan bahwa hukum adat waris memuat peraturan yang mengatur proses pengoperan harta kekayaan baik yang berwujud maupun tidak berwujud dari satu angkatan manusia kepada keturunannya.

Masalah proses pengoperan harta kekayaan menurut Soepomo sudah dapat dimulai semasih orang tua hidup. Proses tersebut menjadi "akuut" oleh

2 Wayan Windia dan Ketut Sudantra, Pengantar Hukum Adat Bali, Lembaga Dokumentasi dan Publikasi, Fakultas Hukum, Universitas Udayana, 2006, h.115..

3 R. Soepomo, Bab-Bab tentang Hukum Adat, Pradnya Paramita, Jakarta, 1986, h. 79.

${ }^{4}$ Surojo Wignjodipuro, Pengantar dan Asas-Asas Hukum Adat, Gunung Agung, Jakarta, 1983, h.167. 
sebab orang tua meninggal dunia ${ }^{5}$. Hal demikian juga dianut dalam hukum adat waris Bali dimana proses pembagian warisan sudah dimulai semasih pewaris hidup dan bagian mana nantinya diperhitungkan dalam pembagian secara tetap setelah pewaris meninggal dunia.

Secara umum untuk dapat berjalannya pewarisan ada tiga unsur penting yang harus dipenuhi yaitu adanya pewaris, harta warisan dan ahli waris. Pewaris adalah orang yang meningglkan warisan sedangkan harta warisan adalah harta yang ditinggalkan oleh pewaris baik yang materiil maupun immateriil. Sementara ahli waris adalah orang-orang yang menerima harta warisan. Unsur yang paling terakhir inilah yang dominan menjadi masalah dalam pewarisan akan tetapi unsur lainnya juga tidak kalah pentingnya karena salah satu dari unsur-unsur pewarisan tidak ada maka pewarisan tidak dapat dilaksanakan. Hanya saja yang paling krusial adalah pada unsur ahli waris.

Siapa itu pewaris? Masyarakat adat Bali yang menganut sistem kekeluargaan patrilineal memandang pewaris adalah ayah. Pandangan ini didasari pemikiran karena laki-laki menerima warisan dari ayahnya dan sudah berlangsung secara turun temurun. Hal senada juga dikatakan oleh windia bahwa pewaris adalah seorang ayah (laki-laki) karena lakilaki pemilik harta keluraga yang diwarisi secara turun temurun dan laki-laki juga pecari nafkah sehingga semua harta milik laki-laki sementara

5 Soepomo, loc.cit. perempuan tidak pemilik harta ${ }^{6}$.

Pandangan hanya laki-laki (ayah) sebagai pewaris, nampaknya mulai terbantahkan mengingat kemajuan jaman dan perkembangan ilmu pengetahuan yang berpengaruh terhadap pola pikir atau mindzet sebagian anggota masyarakat (perempuan) sehingga mereka tidak lagi berkutat pada pekerjaan di sektor domestik (rumah tangga) melainkan juga ikut mencari nafkah dengan bekerja di sektor publik sehingga mempunyai penghasilan yang nantinya dapat diwariskan kepada anakanaknya. Dengan demikian perempuan juga dapat sebagai pewaris karena mempunyai harta. Hal tersebut selaras dengan yang dikemukakan oleh Wirta Griadh bahwa ibupun sebagai pewaris selain ayah ${ }^{7}$. Jadi pewaris tidak lagi hanya laki-laki (ayah) tetapi orang tua yakni ayah dan ibu.

Selain pewaris, unsur penting lainnya untuk berjalannya pewarisan adalah harta warisan. Hilman Hadikusuma mengemukakan bahwa warisan adalah barang-barang berupa harta benda yang ditinggalkan oleh seorang pewaris ${ }^{8}$. Sementara Retnowulan Sutantio mengatakan bahwa harta warisan adalah harta yang ditinggalkan oleh pewaris setelah dikurangi hibah-hibah dan hutanghutang almarhum, biaya penguburan,

6 Wayan P. Windia dan Ketut Sudantra, Loc.Cit.

Ketut Wirta Gridhi, "Sikap Masyarakat Bali Terhadap Kemungkinan Terwujudnya Sistem Hukum Waris Bilateral Individual", Laporan Penelitian, Fakultas Hukum Universitas Udayana, Denpasar, 1990, h. 17.

${ }^{8}$ Hilman Hadikusuma, Pengantar Ilmu

Hukum Adat, CV Mandar Maju, Bandung, 2003, h. 35. 
selamatan, biaya-biaya lainnya sehubungan dengan kematian ${ }^{9}$. Korn mengatakan bahwa menurut Hukum Adat Bali, warisan adalah semua harta kekayaan berupa material (yang berwujud) yang ditinggalkan oleh pewaris ${ }^{10}$.

Mencermati pendapat dari para sarjana yang sudah diungkapkan tersebut di atas, dapat dikatakan bahwa harta warisan adalah segala kekayaan yang ditinggalkan oleh pewaris baik yang berwujud benda maupun yang tidak berwujud benda.

Dalam hukum adat Bali, warisan tidak saja bewujud benda-benda seperti harta keluarga tetapi juga hakhak kemasyarakatan seperti hak atas tanah karang desa, hak memanfaakan kuburan dan hak untuk bersembahyang di pura Kahyangan Desa dan lainlainnya. Dengan adanya hak-hak yang diterimanya tentunya dibarengin dengan kewajiban-kewajiban yang melekat sebagai akibat diterimanya hak-hak tersebut.

Harta warisan keluarga yang berwujud benda dapat digolongan sebagai berikut ${ }^{11}$ :

1. Tetamian (harta pusaka), yaitu berupa harta yang diperoleh karena pewarisan secara turun temurun yang meliputi harta yang tidak dapat dibagi-bagi yakni harta yang mempunyai nilai

9 Retnowulan Sutantio, Wanita dan

Hukum, Alumni, Bandung, 1979, h.86.

${ }^{10}$ V.E Korn, V E Korn, Hukum Adat Waris Bali (Het Adatrecht van Bali Bab IX) diterjemahkan dan diberi catatan-catatan oleh I Gde Wayan Pangkat, Fakultas Hukum \& Pengetahuan Masyarakat, Universitas Udayana, Denpasar, 1972, h. 46.

11 Wayan Windia dan Ketut Sudantra, Op.Cit, h. 117. religius seperti

tempat

persembahyangan

keluarga

(sanggah/merajan) dan lain-

lainnya dan tetamian yang dapat dibagi-bagi yaitu harta warisan yang tidak mempunyai nilai religius seperti sawah, ladang, dan lain-linnya.

2. Tetatadan, yaitu harta yang dibawa oleh masing-masing suami istri yang dibawa masuk ke dalam perkawinan baik yang diperoleh karena usahanya sendiri (sekaya) maupun pemberian/hibah (jiwadana).

3. Pegunakaya/gunakaya, yaitu harta yang diperoleh suami istri selama perkawinan berlangsung.

Dalam Peswara Pewarisan tahun 1900 disebutkan bahwa harta warisan terjadi dari hasil bersih kekayaan pewaris setelah dipotong hutangnya termasuk hutang-hutang yang dibuat untuk ongkos penyelenggaraan pengabenan pewaris ${ }^{12}$. Terhadap hal tersebut terdapat penafsiran bahwa hutang hutang pewaris tidak ditanggung oleh ahli warisnya jika harta warisan tidak mencukupi ${ }^{13}$. Sementara Korn, menulis bahwa tidak saja sisa yang beralih dari harta warisan yang diterima tetapi juga termasuk hutang-hutang pewaris diwariskan kepada ahli warisnya

12 Peswara Pewarisan Tahun 1900 dikeluarkan tanggal 13 Oktober 1900 oleh Residen Bali dan Lombok dengan permusyawarahan bersama-sama pedandapedanda dan punggawa-punggawa. Semula diberlakukan bagi Hindu Bali dari Kabupaten Buleleng, tetapi pada tahun 1915 diberlakukan pula untuk seluruh Bali Selatan.

${ }^{13}$ Gde Panetja, 1986, Aneka Catatan Tentang Hukum Adat Bali, CV. Kayumas, Denpasar, h, 162. 
kecuali hutang-hutang karena perjudian. ${ }^{14}$

Unsur lainnya yang paling esensial adalah ahli waris. Dalam hukum adat Bali mana kala tidak ada ahli waris maka akan dilakukan perbuatan hukum mengangkat anak orang lain yang dijadikan anak sendiri diutamakan anak dari kalangan keluarga sendiri, kalau tidak ada maka pengangkatan dapat dilakukan terhadap orang di luar kalangan keluarga. Bahkan untuk memenuhi unsur ketiga tersebut tidak jarang sang suami melakukan perkawinan poligami untuk menghindari kepunahan keturunan atau melanjutkan generasi, begitu pentingnya unsur yang ketiga tersebut. Siapa itu ahli waris ? Ahli waris adalah orang atau orang-orang yang menerima harta warisan. Akibat orang menjadi ahli waris maka ia dibebani kewajiban-kewajiban baik kewajiban keluarga maupun kewajiban masyarakat adat. Adapun kewajibankewajiban ahli waris yaitu :

1. Memelihara pewaris ketika pewaris dalam keadaan tidak mampu secara fisik;

2. Menguburkan jenazah pewaris atau mengabenkan pewaris serta menyemayamkan arwahnya di sanggah/merajan;

3. Menyembah arwah leluhur yang bersemayan di sanggah/merajan;

4. Melaksanakan kemasyarakatan adat berupa ayahan terhadap banjar/desa adat.

Tidak dilaksanakannya kewajibankewajiban sebagaimana tersebut di atas dapat mengakibatkan dicabutnya hak-hak yang mesti diterimanya, hal mana sesuai dengan asas kesebandingan yakni apabila seorang ahli waris tidak melaksanakan kewajiban maka ia tidak juga mendapatkan hak-haknya.

Ahli waris adalah anak yang lahir dari perkawinan syah orang tuanya, yang menurut hukum adat Bali ahli waris itu adalah anak laki-laki dan anak perempuan yang dirubah statusnya dengan melakukan perkawinan nyeburin. Melalui perkawinan nyeburin sang istri berubah status hukum menjadi purusa yang mana sebelumnya ia berstatus hukum predana sementara sang suami berstatus predana. Purusa bukan berarti laki-laki, karena perempuan yang kawin keceburin juga berstatus purusa. Makna purusa dan predana adalah status, bukan jenis kelamin.

Sebenarnya kalau ahli waris diartikan anak, anak itu ada bermacam-macam yaitu anak kandung, anak tiri, anak angkat, anak piara dan anak luar kawin. Dari jenis anak-anak tersebut mempunyai hak mewaris yang berbeda sesuai dengan statusnya. Anak kandung mempunyai hak penuh terhadap warisan orang tuanya. Sementara anak-anak lainnya mempunyai hak yang terbatas menurut sistem kekeluargaan yang dianut oleh suatu masyarakat tertentu. Menurut hukum adat Bali, selain anak kandung mempunyai hak waris penuh terhadap harta warisan orang tuanya, anak angkat juga mempunyai hak waris penuh terhadap harta warisan orang tua angkatnya. Sangat berbeda dengan anak angkat pada masyarakat parental

${ }^{14}$ V.E. Korn, Op. Cit., h. 8-10. 
di Jawa, dimana anak angkat hanya berhak terbatas terhadap harta gono gini orang tua angkat.

Setelah terpenuhinya unsur-unsur dalam pewarisan yaitu pewaris, harta warisan dan ahli waris maka proses pewarisan dapat dilakukan. Masalahnya kapan pengoperan harta kekayaan atau pewarisan itu dimulai, apa menunggu si pewaris meninggal dunia?. Proses pewarisan sudah dapat dimulai semasih orang tua hidup. Proses tersebut menjadi "akuut" oleh sebab orang tua meninggal dunia ${ }^{15}$. Hal demikian juga dianut dalam hukum adat waris Bali dimana proses pembagian warisan sudah dapat dimulai semasih si pewaris hidup. Pembagian harta warisan semasih pewaris hidup dapat berupa pedum pamong atau pedung raksa, pengupa jiwa, yang merupakan pemberian yang bersifat sementara kepada ahli waris yang tujuannya untuk dimanfaatkan oleh ahli waris dalam penghidupan keluarganya sampi adanya pembagian harta warisan secara tetap. Pengupa jiwa tetap diperhitungkan dalam pembagian harta warisan secara tetap. Harta warisan dibagi oleh para ahli waris secara tetap adalah setelah pewaris meninggal dunia. Setelah pembagian harta warisan secara tetap maka para ahli berhak secara mutlak atas bagian warisan tersebut sesuai dengan porsinya masing-masing karena pembagian warisan secara hukum adat dilakukan atas asas kerukunan, laras dan patut atau tidak berdasarkan ilmu hitung atau matematika yang tentunya dibarengi dengan kewajiban-kewajiban

15 Soepomo, loc.cit. yang harus dilakukan oleh para ahli waris.

Jadi tidak ada aturan atau ketentuan yang tegas tentang bagian masing-masing ahli waris, kecuali perbandingan bagian antara anak lakilaki dan perempuan yang belum kawin, yaitu dua berbanding satu atau ategen $\operatorname{asuun}^{16}$

Bagaimana jika ahli waris meninggal sebelum harta warisan dibagi? Terhadap hal demikian tidak menimbulkan masalah karena kedudukan ahli waris akan ditutup atau diisi oleh ahli waris pengganti. Ahli waris pengganti adalah anak dari ahli ahli waris yang sebenarnya, dimana ahli waris pengganti akan menggantikan posisi sang ayah dan posisinya sama dengan saudarasaudara ayahnya.

Harta warisan yang dapat dibagi secara individu oleh para ahli waris adalah harta warisan yang tidak bernilai religio magis seperti sawah, ladang, deposito, dan lain-lainnya. Sementara harta warisan yang bernilai religio magis seperti tempat pemujaan atau tempat persembahyangan yaitu sanggah/merajan tidak dapat diwarisi secara individu, melainkan terhadap hal tersebut diwarisi secara kolektif oleh para ahli waris.

\section{Kedudukan Ahli Waris Yang Beralih Agama dan Akibat Hukumnya.}

Dalam hukum adat umumnya dan dalam hukum adat Bali khususnya pada pewarisan antara hak-hak dan kewajiban-kewajiban terutama kewajiban terhadap keluarga yakni

${ }^{16}$ Wayan Windia dan Ketut Sudantra, Op.Cit., h. 122. 
kewajiban terhadap orang tua atau pewaris selalu bergandengan. Mana kala ahli waris tidak melaksanakan kewajiban seperti memelihara orang tua, menguburkan atau mengabenkan (membakar jenazah) pewaris setelah meninggal dunia, menyemayamkan arwahnya di sanggah/merajan dan memuja atau menyembah arwah leluhur sudah tentu terhadap ahli waris demikian berakibat tidak patut dan pantas mendapatkan menjadi hakhaknya. Terkait dengan kewajibankewajiban yang harus ditanggung ahli waris tersebut lantas bagaimana dengan ahli waris yang beralih agama dari agama Hindu menjadi non Hindu dapatkah dilakukannya?

Hasil penelitian menunjukan bahwa dari para informan yang dimintai pendapatnya dapat disimpulkan bahwa ahli waris yang beralih agama tidak lagi berkedudukan sebagai ahli waris sehingga ia tidak dapat melaksanakan kewajibankewajibannya sebagaimana mestinya seperti memelihara orang tua, menguburkan atau mengabenkan/membakar jenazah pewaris setelah meninggal dunia serta menyemayamkan arwah leluhur di sanggah/merajan, menyembah arwah leluhur, dan melaksanakan kewajiban adat seperti ngayah di banjar atau di desa. Dengan demikian maka hakhaknya juga tidak didapatnya atau hak mewarisnya telah gugur dengan beralih agama dari ahli waris yang bersangkutan, kecuali adanya pemberian dari orang tua atas kesepakan keluarga. Pemberian hanya bersifat manusiawi karena pemberian bukanlah hak. Terkait dengan hal itu Ayu Nantri mengemukakan bahwa alhi waris yang beralih agama tidak berkedudukan sebagai ahli waris sehingga tidak berhak mewaris ${ }^{17}$.

Gugurnya hak mewaris dari ahli waris dapat disebabkan oleh beberapa hal, sebagaimana disebutkan dalam diskusi Hukum Adat Waris Bali tahun 1971 bahwa ahli waris terputus haknya menerima harta warisan antara lain: ${ }^{18}$

1. Anak laki-laki yang kawin nyeburin;

2. Anak laki-laki yang tidak melaksanakan dharmaning anak, misalnya durhaka terhadap leluhur, terhadap orang tua;

3. Sentana rajeg yang kawin ke luar. Mencermati hasil diskusi hukum adat Bali tersebut, dimana ahli waris yang beralih agama dapat diasumsi bahwa ahli waris yang bersangkutan tidak melaksanakan dharmaning anak yaitu durhaka terhadap leluhur sehingga terhadapnya tidak patut dan pantas menerima hak-haknya dalam mewaris. Sementara terhadap anak laki-laki yang kawin nyeburin gugur hak warisnya sekarang sudah mengalami perubahan berdasarkan hasil keputusan Pesamuhan Agung III Majelis Utama Desa Pakraman (MUDP) Propinsi Bali tahun 2010. Dalam keputusan salah satu butirnya disebutkan bahwa anak laki-laki yang kawin nyeburin berhak atas harta guna kaya orang tuanya dengan perbandingan dua bagian untuk anak

17 Ayu Putu Nantri, "Kedudukan Ahli Waris Yang Beralih Agama di Kabupaten Badung", Laporan Penelitian, Fakultas Hukum,Universitas Udayana, Denpasar, 1982, h. 14.

${ }^{18}$ V.E. Korn, Op.Cit. h. 19. 
laki-laki yang tidak kawin nyeburin dan satu bagian untuk anak laki-laki kawin nyeburin setelah dikurangi sepertiga untuk harta bersama. Bagian hak tersebut adalah sama porsinya dengan bagian hak anak perempuan.

Dengan gugurnya hak mewaris dari ahli waris yang beralih agama maka ia tidak berhak terhadap harta warisan warisan orang tuanya dan secara otomatis tidak juga ada kewajiban-kewajiban yang harus dilakukannya, kecuali kewajiban moral atau manusiawi terhadap orang tuanya yang telah melahirkan dan membesarkannya.

Mencermati ahli waris beralih agama, dikaji berdasarkan Teori Sistem Hukum dari Lawrence M. Friedman ${ }^{19}$, sistem hukum terdiri dari tiga unsur yautu sutruktur hukum, substansi hukum, dan budaya hukum, dimana dari ketiga unsur tersebut tidak mengalami perkembangan. Artinya hukum adat waris Bali masih tetap dipertahankan secara utuh.

\section{KESIMPULAN DAN SARAN}

\section{Kesimpulan.}

Dari beberapa paparan atau uraian tersebut di atas maka dapat disimpulkan sebagai sebagai berikut :

1. Ahli waris yang beralih agama dari agama Hindu ke non Hindu tidak lagi berkedudukan sebagai ahli waris karena bagi ahli waris yang beralih agama tidak dapat melaksanakan kewajibankewajiban keluarga secara adat dan agama Hindu.

19 Lawrence M. Friedman, Law and Society, An Introduction, Prenitice Hall, New Jersey, 1977, h. 7.
2. Akibat hukum yang ditimbulkan dengan adanya ahli waris yang beralih agama adalah gugurnya hak mewaris terhadap harta kekayaan orang tua dari ahli waris tersebut. Gugurnya hak mewaris dari ahli waris yang bersangkutan tentunya tidak adanya kewajibankewajiban yang dipikulnya baik kewajiban keluarga maupun kewajiban kemasyarakatan.

\section{Saran}

Melalui laporan penelitian ini disarankan kepada masyarakat adat Bali umumnya dan masyarakat adat atau Desa Pakraman Canggu khususnya agar tetap menjaga hukum adat Bali sebagai ciri khas yang dijiwai oleh agama Hindu. Ini berarti tidak menutup diri dari perkembangan jaman mengingat hukum adat sebagai hukum yang hidup mempunyai sifat luwes dan dinamis. Di samping itu dalam hal adanya ahli waris beralih agama hendaknya diatur secara tegas dan jelas dalam awig-awig desa pakraman bahwa hak-haknya gugur dan tidak dibebani kewajiban-kewajiban. 


\section{DAFTAR PUSTAKA}

Gridhi, Ketut Wirta, 1990, "Sikap Masyarakat Bali Terhadap Kemungkinan Terwujudnya Sistem Hukum Waris Bilatral Individual", Laporan Penelitian, Facultas Hukum Universitas Udayana, Denpasar.

Friedman, Laurence M., 1977, Law and Society, An Introduction, Prenitice Hall, New Jersey.

Hadikusuma, Hilman, 2003, Pengantar Ilmu Hukum Adat, CV Mandar Maju, Bandung.

Hazairin, 1982, Hukum Kekeluargaan Nasional, Tintamas, Jakarta.

Nantri, Ayu Putu, 1982, "Kedudukan Ahli Waris Yang Beralih Agama di Kabupaten Badung”, Laporan Penelitian, Fakultas Hukum, Universitas Udayana, Denpasar.

Panetja, Gde, 1986, Aneka Catatan Tentang Hukum Adat Bali, CV. Kayumas, Denpasar.

Sutantio, Retnowulan, 1979, Wanita dan Hukum, Alumni, Bandung.

R. Soepomo, R, 1986, Bab-Bab tentang Hukum Adat, Pradnya Paramita, Jakarta.

Korn, V.E, 1972, Hukum Adat Waris di Bali(Het Adatrecht Van Bali-Bab IX), diterjemahkan dan diberi catatan-catatan oleh I Gde Wayan Pangkat, Fakultas Hukum \& Pengetahuan Masyarakat, Universitas Udayana, Denpasar.

Wignjodipuro, Surojo, 1967, Pengantar Dan Asas-Asas Hukum Adat, Gunung Agung, Jakarta.

Windia, I Wayan P., I Ketut Sudantra, 2006, Pengantar Hukum Adat Bali, Lembaga Dokumentasi dan Publikasi Hukum, Fakultas Hukum Universitas Udayana.

Peswara Pewarisan Tahun 1900 dikeluarkan tanggal 13 Oktober 1900 oleh Residen Bali dan Lombok dengan permusyawarahan bersama-sama pedandapedanda dan punggawa-punggawa. Semula diberlakukan bagi Hindu Bali dari Kabupaten Buleleng, tetapi pada tahun 1915 diberlakukan pula untuk seluruh Bali Selatan. 